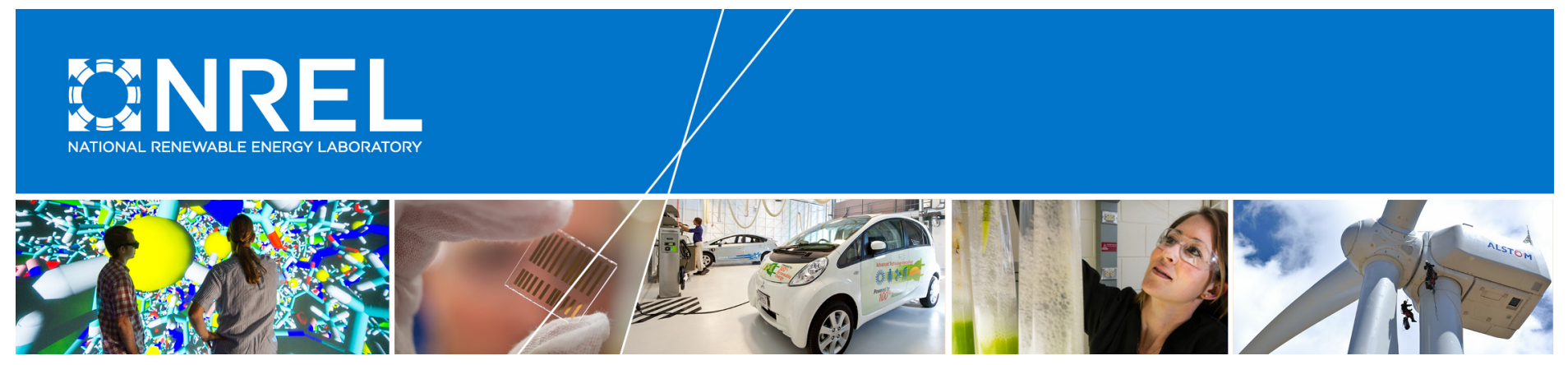

\title{
Quantifying the Opportunity Space for Future Electricity Generation: An Application to Offshore Wind Energy in the United States
}

Cara Marcy and Philipp Beiter National Renewable Energy Laboratory

NREL is a national laboratory of the U.S. Department of Energy Office of Energy Efficiency \& Renewable Energy Operated by the Alliance for Sustainable Energy, LLC

This report is available at no cost from the National Renewable Energy Laboratory (NREL) at www.nrel.gov/publications.

Technical Report

NREL/TP-6A20-66522

September 2016

Contract No. DE-AC36-08GO28308 


\section{Quantifying the Opportunity Space for Future Electricity Generation: An Application to Offshore Wind Energy in the United States}

Cara Marcy and Philipp Beiter

National Renewable Energy Laboratory

Prepared under Task No. WE15.5C01

NREL is a national laboratory of the U.S. Department of Energy Office of Energy Efficiency \& Renewable Energy Operated by the Alliance for Sustainable Energy, LLC

This report is available at no cost from the National Renewable Energy Laboratory (NREL) at www.nrel.gov/publications.

National Renewable Energy Laboratory 15013 Denver West Parkway Golden, CO 80401

303-275-3000 • www.nrel.gov
Technical Report

NREL/TP-6A20-66522

September 2016

Contract No. DE-AC36-08G028308 


\section{NOTICE}

This report was prepared as an account of work sponsored by an agency of the United States government. Neither the United States government nor any agency thereof, nor any of their employees, makes any warranty, express or implied, or assumes any legal liability or responsibility for the accuracy, completeness, or usefulness of any information, apparatus, product, or process disclosed, or represents that its use would not infringe privately owned rights. Reference herein to any specific commercial product, process, or service by trade name, trademark, manufacturer, or otherwise does not necessarily constitute or imply its endorsement, recommendation, or favoring by the United States government or any agency thereof. The views and opinions of authors expressed herein do not necessarily state or reflect those of the United States government or any agency thereof.

This report is available at no cost from the National Renewable Energy Laboratory (NREL) at www.nrel.gov/publications.

Available electronically at SciTech Connect http:/www.osti.gov/scitech

Available for a processing fee to U.S. Department of Energy

and its contractors, in paper, from:

U.S. Department of Energy

Office of Scientific and Technical Information

P.O. Box 62

Oak Ridge, TN 37831-0062

OSTI http://www.osti.gov

Phone: 865.576 .8401

Fax: 865.576.5728

Email: reports@osti.gov

Available for sale to the public, in paper, from:

U.S. Department of Commerce

National Technical Information Service

5301 Shawnee Road

Alexandria, VA 22312

NTIS http://www.ntis.gov

Phone: 800.553 .6847 or 703.605 .6000

Fax: 703.605.6900

Email: orders@ntis.gov 


\section{Acknowledgments}

We thank Wesley Cole, Dave Corbus, Jeffrey Logan, Walt Musial, Aaron Smith, and Brian Smith (National Renewable Energy Laboratory), and Chris Namovicz (U.S. Energy Information Administration) for their thoughtful reviews, comments, and suggestions. We also thank Alana Duerr, Greg Matzat, and Jose Zayas (U.S. Department of Energy) for their contributions. This work was supported by the U.S. Department of Energy under Contract Number DE-AC3608GO28308 with the National Renewable Energy Laboratory. Funding for the work was provided by the DOE Office of Energy Efficiency and Renewable Energy, Wind and Water Power Technologies Office. Any remaining errors or omissions are the sole responsibility of the authors.

Editing was provided by Sheri Anstedt (National Renewable Energy Laboratory). 


\section{List of Acronyms}

BOEM

CAGR

DOE

EIA

GW

LCOE

MW

MWh

NREL

TW

TWh
Bureau of Ocean Energy Management

Compound Annual Growth Rate

U.S. Department of Energy

U.S. Energy Information Administration gigawatt levelized cost of energy

megawatt

megawatt-hour

National Renewable Energy Laboratory

terawatt

terawatt-hour 


\section{Executive Summary}

This report provides a high-level assessment of the future demand for additional electric power generation that is not met by existing generation sources. The timeframe for this work covers from 2015 to 2050. The metric developed in this report is applied to coastal regions, including the Great Lakes, to assess the regional opportunity space for offshore wind. An assessment of opportunity space can be a first step in determining the prospects and system value of a technology. The metric provides an estimate for the amount of additional generation that is potentially required to satisfy demand in future years.

For the purpose of this report, "opportunity space" in any given year is broadly defined as the difference between the electricity generation from existing power plants and the expected demand. Imports to a region are considered part of the opportunity space. The indicator takes into account generation from existing power plants in 2015, load growth projections, and retirement of existing power plants. Scheduled and projected capacity additions are not considered for this analysis to allow for a more transparent definition of the opportunity space, eliminating any uncertainty that may arise in planned capacity additions and different lengths of time needed for planning and construction between different technology types. The data for future electricity generation retirements and demand (load) for this analysis are derived from published data and reports from the Energy Information Administration, the National Renewable Energy Laboratory, and the ABB Velocity Suite. Electricity generation was derived from reported installed capacity by applying a constant capacity factor throughout the timeframe considered. Capacity factors were calculated at the individual power plant level using the weighted average of monthly capacity factors reported in 2014 (where data were available).

This analysis indicates a total U.S. ${ }^{1}$ opportunity space of nearly 3,000 terawatt-hours (TWh) to be available by 2050 . This amount is based on an average national annual load growth of $0.66 \%$ (Compound Annual Growth Rate [CAGR]) and cumulative retirements from nuclear, coal, gas/petroleum, and renewable sources of nearly $2,000 \mathrm{TWh}$ by 2050 . For comparison, the U.S. total electricity net generation in 2015 is approximately 4,100 TWh (Energy Information Administration 2015a). For coastal regions ${ }^{2}$ alone, the analysis shows that nearly $2,400 \mathrm{TWh}$ of opportunity space is available by 2050 (see Figure ES-1). The average annual load growth projected for coastal regions is $0.62 \%$ (CAGR) and cumulative retirements from nuclear, coal, gas/petroleum, and renewable sources total nearly 1,500 TWh between 2015 and 2050. Coastal opportunity space is distributed among the Great Lakes (688 TWh), South Atlantic (555 TWh), Gulf Coast (502 TWh), Pacific (348 TWh), and North Atlantic (289 TWh) regions.

These estimates of opportunity space can be compared to estimates of resource potential of a generation technology such as offshore wind. A recent National Renewable Energy Laboratory assessment (Musial et al. 2016) estimated the total U.S. technical potential ${ }^{3}$ of offshore wind to be more than 7,200 TWh, which exceeds coastal opportunity space threefold.

\footnotetext{
${ }^{1}$ Contiguous United States (excludes Hawaii and Alaska).

${ }^{2}$ Excludes Hawaii and Alaska, but includes the Great Lakes region.

${ }^{3}$ Offshore wind technical potential captures "the subset of gross recoverable resource potential that can be considered recoverable under available technological and turbine performance conditions while considering land-use and environmental siting constraints" (Beiter and Musial 2016).
} 


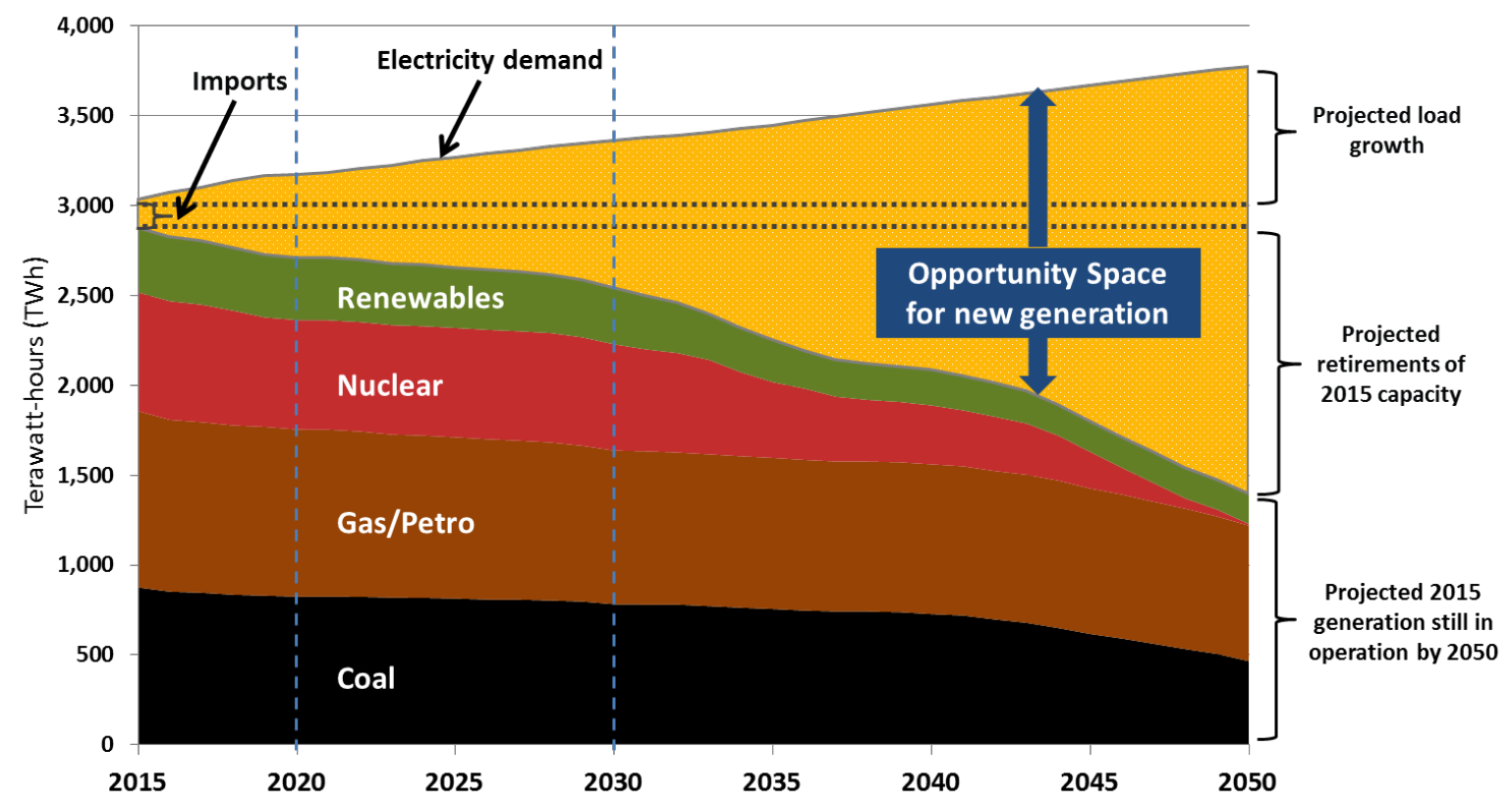

ES-1. Opportunity space and projected electricity generation from existing units in coastal regions from 2015 to 2050

Some limitations apply to this analysis that should be considered when interpreting the results. These include the assumption of static import-export relationships and the nonconsideration of integration challenges, planned or scheduled capacity additions, unscheduled economic or other early retirements (e.g., as a result of policies that may force units to retire before their expected lifespan), policy mandates (such as state renewable portfolio standards and goals), nonscheduled relicensing, unplanned repowering, or other unplanned uprates and/or conversions. In addition, capacity factors are held constant throughout the timeframe of this report. Significant reductions from energy efficiency measures are not explicitly considered to adjust demand (load) projections. 


\section{Table of Contents}

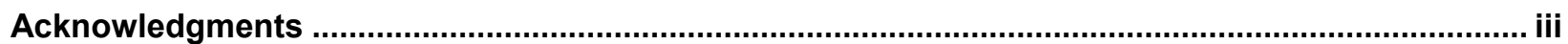

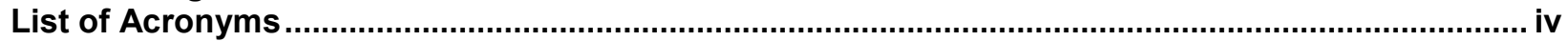

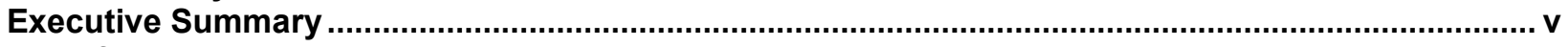

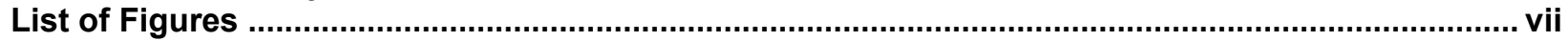

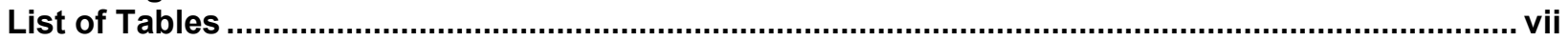

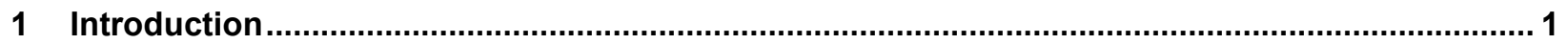

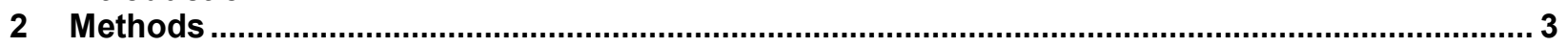

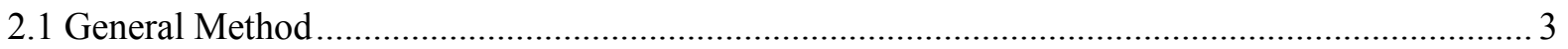

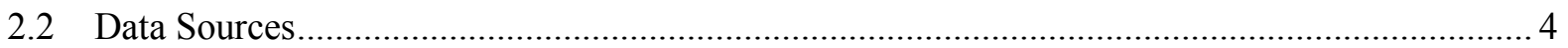

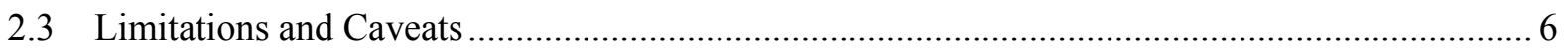

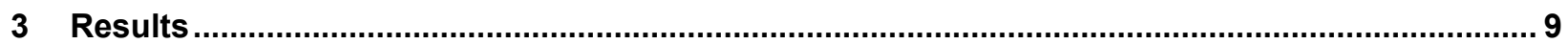

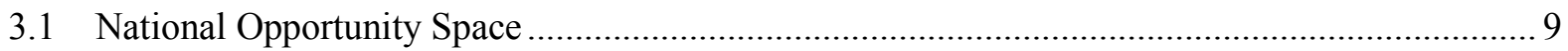

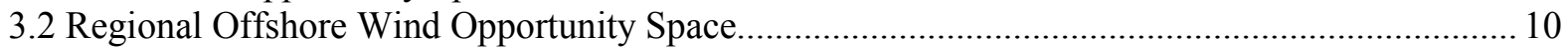

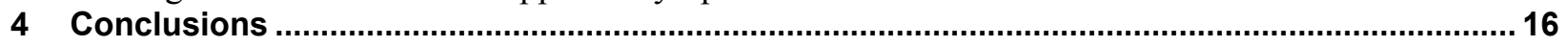

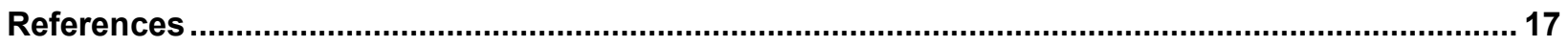

Appendix

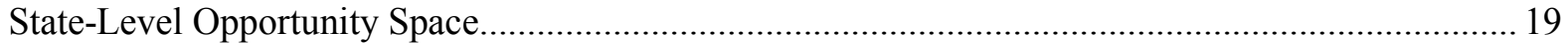

\section{List of Figures}

ES-1. Opportunity space and projected electricity generation from existing units in coastal regions from 2015 to 2050

Figure 1. The opportunity space and projected electricity generation from existing units in coastal regions from 2015 to 2050 .

Figure 2. Opportunity space and projected net electricity generation from existing units for the

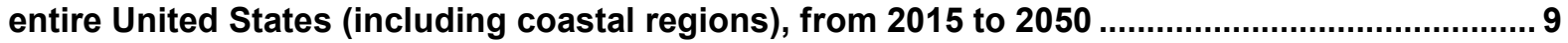

Figure 3. U.S. offshore wind regional map. Figure from the Wind Vision (DOE 2015) ..................... 10

Figure 4. The opportunity space and projected electricity generation from existing units in each

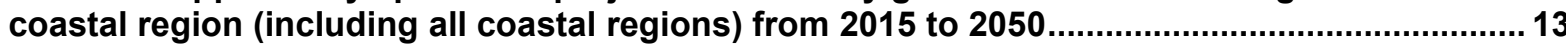

Figure A-1. The opportunity space and projected electricity generation from existing units for

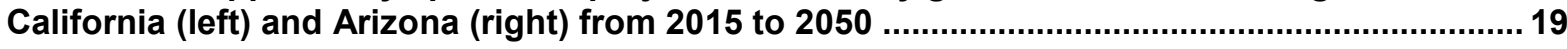

\section{List of Tables}

Table 1. Estimated Lifespan of Conventional Generators by Fuel Type ........................................5

Table 2. Estimated Lifespan of Renewable Technologies ................................................................ 5

Table 3. U.S. Electricity Demand, Remaining Generation by Source, and Opportunity Space from

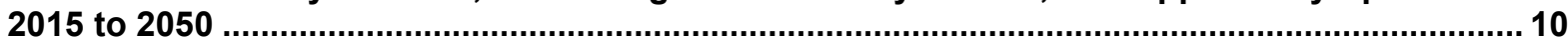

Table 4. The Opportunity Space and Scheduled/Age-Based Retirements for the Coastal Regions from 2015 to 2050

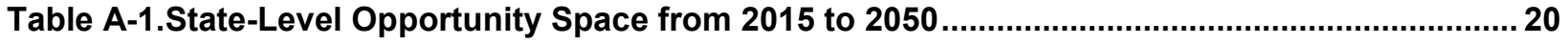




\section{Introduction}

Technology advancements have led to a significant and continuous decline in the levelized cost of energy (LCOE) across many renewable energy technologies. This trend is reflected in offshore wind production costs. Between 2010 and 2014 alone the estimated LCOE for a representative (3.39-megawatt [MW] fixed-bottom) future offshore wind project in the United States has decreased by more than $23 \%$ - from 252 dollars per megawatt-hour $(\$ / \mathrm{MWh})^{4}$ to 193 $\$$ MWh (Moné et al. 2015). With growing deployment and maturing markets in Europe and Asia and a nascent industry in the United States, offshore wind production costs are likely to decline further in future years (Catapult 2015; The Carbon Trust 2015; Moné et al. 2015; Smith, Stehly, and Musial 2015; Beiter et al. 2016). As interest from prospective U.S. developers to examine commercial opportunities for offshore wind deployment grows, considerations of future demand and system-wide benefits of this technology become increasingly important. The deployment and commercial operation of offshore wind in Europe and Asia has proven that the technology can be installed and connected and can deliver electricity to the existing electrical grid on a large scale. In Denmark, almost $43 \%$ of the country's electricity-generating capacity comes from wind energy with over $25 \%$ of that fraction from offshore wind (Danish Ministry of Foreign Affairs 2016). In the United Kingdom, there are over 5 gigawatts (GW) of offshore wind to date, supplying approximately 15 terawatt-hours per year (TWh/yr) to the grid (RenewableUK 2016). Daniel et al. (2014) show that the U.S. grid has the ability to integrate up to $54 \mathrm{GW}$ of offshore wind by 2030 without major upgrades. As a result, parts of the U.S. electric industry are anticipated to shift increasingly towards including offshore wind in state and regional market planning. This shift will help sharpen an understanding of where the technology can provide the highest value to the electrical system now and in the future. A key component of assessing the system value of any technology, particularly a nascent technology such as offshore wind, is future demand for electrical energy.

This report provides a high-level indicator of the future electricity demand for additional electric power generation that is not met by existing generation sources. The timeframe for this work is 2015-2050. For the purpose of this report, "opportunity space" in any given year is broadly defined as the difference between the generation from existing power plants and the expected demand. The assessment takes into account generation from existing power plants in 2015, load growth projections, and retirement of existing power plants. Scheduled and projected capacity additions are not considered. The data for future electricity generation retirements and demand (load) for this analysis are derived from data and reports from the Energy Information Administration (EIA), National Renewable Energy Laboratory (NREL), and the ABB Velocity Suite. This assessment of opportunity space can be a first step in determining the prospects and system value of adding a new generation technology to the electric grid. It provides an estimate of the amount of additional generation that will likely be required to satisfy demand in future years.

This initial assessment includes opportunity space across the entire contiguous United States. Because the motivation for this report was to study regional opportunities for offshore wind, results of this analysis are also presented for the subset of the 28 states with a coastal boarder, including the Great Lakes (see Figure 3). The opportunity space calculated herein is available to

\footnotetext{
${ }^{4}$ All dollars are reported in $2014 \$$, if not denoted otherwise.
} 
any generation technology, both conventional and renewable energy, and is not a projection of actual deployment for any particular technology. The analysis considers domestic and crossborder exports and imports within the defined regions, so individual states or regions may show more electricity generation than their respective demand, or vice versa. Overall, the sum of the differences between electricity generation and demand of all states or regions included in this analysis is zero. For the purpose of this analysis, imports to a region are considered part of the opportunity space and no assumption is made with regards to the share of exports and imports throughout the time period considered. Some additional limitations that should be considered when interpreting these results include the nonconsideration of integration challenges, planned or scheduled capacity additions, ${ }^{5}$ unscheduled economic or other early retirements (e.g., as a result of policies that may force units to retire before their expected lifespan), nonscheduled relicensing, unplanned repowering, or other unplanned uprates and/or conversions. In addition, capacity factors are held constant at 2014 levels throughout the timeframe of this report.

This analysis follows a series of related efforts to understand the prospects of offshore wind in the United States. In March 2015, the U.S. Department of Energy (DOE) published Wind Vision: A New Era for Wind Power in the United States (DOE 2015a). This report examined a detailed study scenario for the United States to establish 35\% of its electricity from wind energy by 2050 , using both land-based and offshore wind. The Wind Vision study scenario estimates that $86 \mathrm{GW}$ of offshore wind power capacity could be deployed in the nation by 2050 and provides a highlevel road map of the actions necessary to realize this scenario. The analysis shows that offshore wind could contribute to all regions of the United States, including the North and South Atlantic Ocean, Gulf of Mexico, Great Lakes, and Pacific Ocean (including California, Oregon, Washington, and Hawaii), although varying regional market conditions and technology requirements may dictate a wide range of deployment timelines (Smith, Stehly, and Musial 2015).

In 2016, DOE and the Bureau of Ocean Energy Management (BOEM) began developing a new offshore wind strategy. This NREL report can help provide data to guide the development of deployment targets for offshore wind in the United States, and illuminate possible regional opportunities to expand offshore wind under specific market conditions.

In Section 2 of this report, the method developed to assess the opportunity space is discussed. It covers data sources and limitations of the model. Section 3 describes the analysis results and additional graphs and results tables are included in the appendix.

\footnotetext{
${ }^{5}$ Scheduled and projected capacity additions are not considered for this analysis to allow for a more transparent definition of the opportunity space, eliminating any uncertainty that may arise in planned capacity additions and different lengths of time needed for planning and construction.
} 


\section{Methods}

This section describes the methods used to estimate the opportunity space for offshore wind generation. It includes a discussion of the general methodology and equations used (Section 2.1), followed by a description of data sources (Section 2.2), and limitations of the model (Section 2.3).

\subsection{General Method}

The purpose of this analysis is to provide a high-level estimate of the additional generation that will be required to meet electricity demand in the United States in future years. Opportunity space takes into account generation in 2015 from existing power plants, load growth projections, and retirement of existing power plants. More precisely, the opportunity space in any given year is defined as the difference between the generation from existing power plants and the expected demand. For each region, the opportunity space $(O S)[\mathrm{MWh}]$ in year $T$ is determined using Eq. 1, where $D_{T}[\mathrm{MWh}]$ is the total electricity demand in year $T, O p_{2015}[\mathrm{MWh}$ ] is the electricity generation from operating generators as reported in early 2015, and $R_{t}[\mathrm{MWh}]$ is the sum of the estimated generation from retired capacity in a given year $t$.

$$
O S_{T}=D_{T}-O p_{2015}+\sum_{t=2015}^{T} R_{t}
$$

$O p_{2015}$ and $R_{t}$ are determined using Eq. 2 and Eq. 3, where $\operatorname{Cop}_{2015, x}[\mathrm{MW}]$ is the operating net summer capacity of generator $x$ in year 2015, $C r_{t, x}$ [MW] is the retired net summer capacity of generator $x$ in a given year $t, C F_{x}[\%]$ is the assumed capacity factor of an individual generator unit $x$ (assumed to be constant at 2014 levels across individual plants and for all years $t$ ), and $8,760[\mathrm{~h}]$ is the number of hours in a year.

$$
\begin{aligned}
O p_{2015} & =\sum_{x} \operatorname{Cop}_{2015, x} * C F_{x} * 8760 \\
R_{t} & =\sum_{x} C r_{t, x} * C F_{x} * 8760
\end{aligned}
$$

Any difference between generation and demand in 2015 can be attributed to imports from outside the region. For the purpose of this analysis, imports to a region are considered part of the opportunity space and no assumption is made with regards to the share of exports and imports throughout the time period considered. Figure 1 illustrates the different components described in the equations and explanation provided earlier for U.S. coastal regions. 


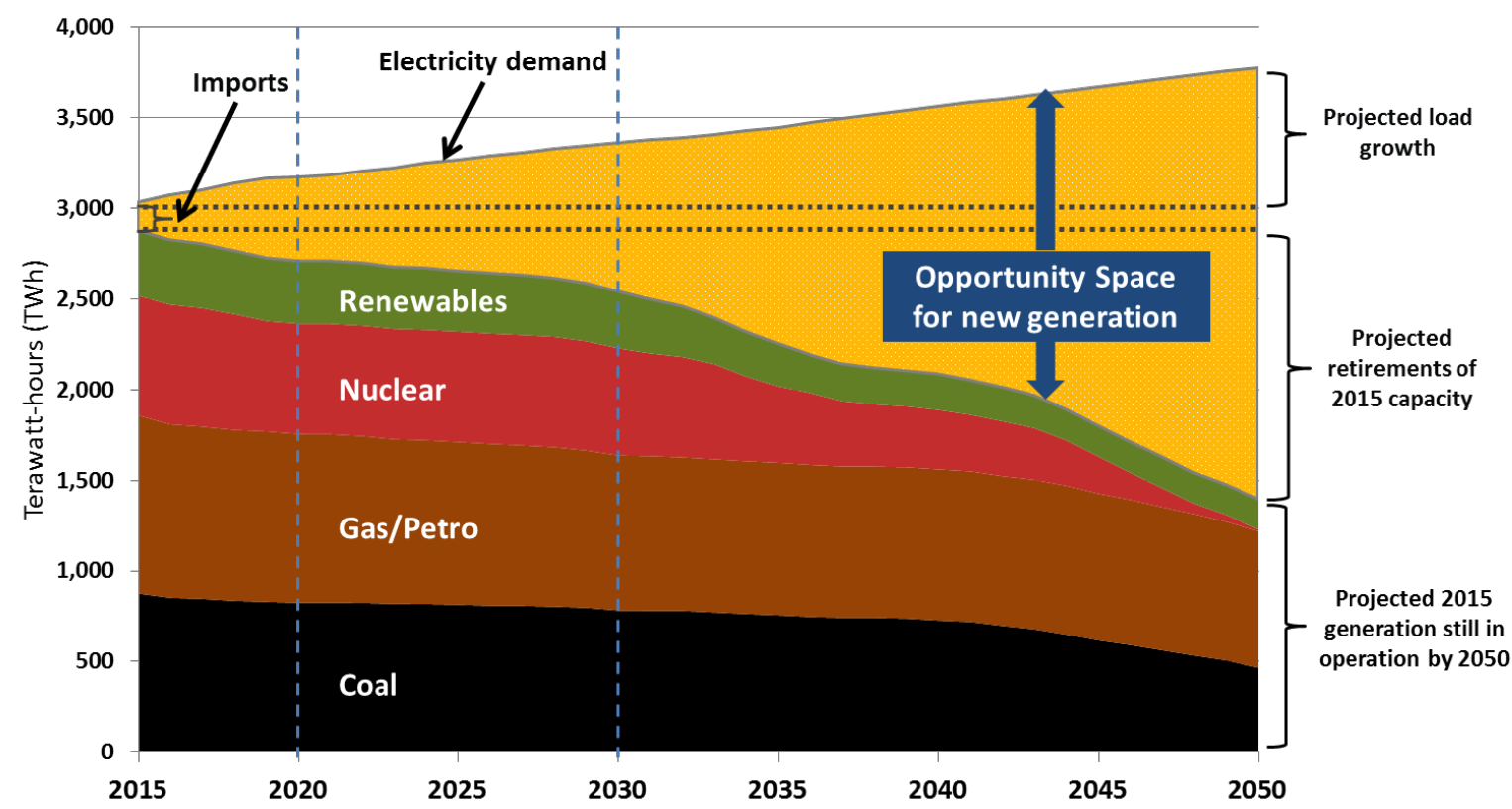

Figure 1. The opportunity space and projected electricity generation from existing units in coastal regions from 2015 to 2050

Figure 1 serves the purpose of illustrating the terms introduced in this section. In the figure, "electricity demand" is the estimated annual electricity demand from 2015 to 2050, "projected load growth" is the annual difference between the electricity demand in 2015 and the projected electricity demand in future years (2015-2050), "imports" represent the estimated 2015 interregional electricity imports (interstate or regional trading), "projected retirements of 2015 capacity" consist of the annual retirements of 2015 capacity based on scheduled retirements and age of generating units from 2015 to2050, "projected 2015 generation still in operation by 2050" represents the generation from 2015 still in service after scheduled and age-based retirements from 2015 to 2050, and the "opportunity space for new generation" is the difference between the generation from currently existing power plants and expected demand.

\subsection{Data Sources}

This analysis is based on a combination of data sources provided by EIA, NREL, and the ABB Velocity Suite.

Estimates for demand (2015-2050) by state were extracted from input assumptions used in NREL's Regional Energy Deployment System (ReEDS) model, a capacity expansion and dispatch model for the contiguous United States (Sullivan et al. 2015; Short et al. 2011). ReEDS inputs are derived from projections published in the Annual Energy Outlook 2014 Reference Case (EIA 2014). These values were used throughout 2040; demand between 2040 and 2050 was based on the assumption of a constant growth rate identical to the Annual Energy Outlook load growth rate from 2039 to 2040 . Significant reductions from energy efficiency measures are not explicitly considered to adjust demand (load) projections in this analysis. The demand represented in this analysis is busbar load, therefore a 5.3\% multiplier was included to account for distribution losses (Sullivan et. al. 2015). 
The 2015 operating capacity is reported at the generator level and was extracted from ABB Velocity Suite (2015), which reflects information from Form EIA-860 (EIA 2015b). Operating capacity includes utility-scale generators online as of December 31, 2014. It does not include capacity from distributed generation or nongrid-connected generation. ${ }^{6}$

Retired capacity by year (2015-2050) for nonrenewable technologies was derived from ABB Velocity Suite (2015) based on individual power plant retirements. Two types of retirements were considered for this analysis: scheduled and age-based. Scheduled retirements are derived primarily from Form EIA-860 (EIA 2015b) and additional market research from ABB Velocity Suite (2015). If a retirement date for a power plant was not reported under Form EIA-860 or determined from ABB Velocity Suite's additional market research, the retirement date was estimated based on the average lifespan of a fuel type. The ABB Velocity Suite (2015) assumed lifespans for fuel types (summarized in Table 1).

Table 1. Estimated Lifespan of Conventional Generators by Fuel Type

\begin{tabular}{|c|c|}
\hline Fuel Type & Estimated Lifespan (Years) \\
\hline Coal $>100 \mathrm{MW}$ & 75 \\
\hline Coal $<100 \mathrm{MW}$ & 65 \\
\hline All Other Fossil Fuel & 55 \\
\hline Nuclear & 60 \\
\hline
\end{tabular}

Source: ABB Velocity Suite 2015

The assumed lifespan of renewable technologies corresponds to the estimates of average lifetimes in the ReEDS model (Sullivan et al. 2015; Short et al. 2011). Table 2 indicates the assumed lifespan for different renewable technologies that were applied in this analysis.

Table 2. Estimated Lifespan of Renewable Technologies

\begin{tabular}{|c|c|}
\hline Technology & Assumed Lifespan (Years) \\
\hline Hydropower & 100 \\
\hline Geothermal & 30 \\
\hline Biopower & 45 \\
\hline Landfill gas & 30 \\
\hline Wind (Land-Based and Offshore) & 24 \\
\hline Concentrating Solar Power & 30 \\
\hline Utility Photovoltaic & 30 \\
\hline
\end{tabular}

Sources: Sullivan et al. 2015; Short et al. 2011

Capacity factors are assumed to be constant in this analysis throughout the timeframe considered and are calculated at the individual power plant level using the weighted average of monthly capacity factors from 2014 (where data were available). The primary source for power-plantlevel capacity factors was Form EIA-923 (EIA 2015g).

A subset of electric power plants (approximately 2\% of the 2015 capacity) does not have capacity factors for 2014 reported under Form EIA-923. For instance, power plants that came

\footnotetext{
${ }^{6}$ Utility-scale generators are typically defined as a plant operating at or above 1-MW capacity and classified under the North American Industry Classification System code 22.
} 
online during 2014 do not have a full year's data available. If power-plant-level capacity factor data were not available, national-level capacity factors were assumed. National average capacity factors were derived from EIA (EIA 2015c, 2015d). Power plant units with a capacity factor of zero (approximately $3 \%$ of the 2015 capacity), such as those reported as having an "out of service" operational status for 2014, were assigned an average capacity factor, assuming they would resume service. Power plant units with a capacity factor below zero (approximately $3 \%$ of the 2015 generator capacity), such as pumped storage, were assigned a capacity factor of zero.

Finally, data were aggregated by state, coastal region, or at the national level to provide insight into the generation mix and opportunity space at different levels of geospatial resolution.

\subsection{Limitations and Caveats}

This analysis provides a high-level, first-pass indicator of the opportunity space that is available to any generation technology. The motivation for this analysis was to identify the opportunity space for offshore wind, therefore, results are shown for coastal regions. Opportunity space as defined in this report captures an estimate for the amount of additional generation that is likely required to satisfy demand in future years. The opportunity space estimated in this report is not available exclusively to a particular technology or a projection of actual deployment. There are a number of underlying assumptions that should be taken into consideration when interpreting these data:

- This analysis is based on annual generation data and does not consider integration challenges that arise with meeting instantaneous, hourly, or seasonal demand. Variable generation (e.g., wind and solar) may not be able to displace generation from dispatchable units (e.g., coal and nuclear) interchangeably. For example, the generation from a nuclear plant that produces electricity 24 hours a day cannot entirely be offset by a solar plant, which generates only during daylight hours. ${ }^{7}$

- Estimates for demand (2015-2050) by state were extracted from input assumptions used in NREL's ReEDS model, which are derived from projections published in the Annual Energy Outlook 2014 Reference Case (EIA 2014). Significant reductions from energy efficiency measures are not explicitly considered to adjust demand (load) projections in this analysis.

- Some assumptions made in this analysis may result in underestimating generation from 2015 that may be available in the future, thereby effectively overestimating opportunity space, such as excluding planned or scheduled capacity additions, upgrades, relicensing, nuclear power plant uprates, ${ }^{8}$ or other nonscheduled changes in capacity to the existing fleet, including immediate retirement of aging generating units, and excluding distributed generation. There are several reasons for making these assumptions:

- Capacity estimates in this analysis do not include planned or scheduled capacity additions. Excluding planned additions allows for a more transparent definition of the opportunity space and eliminates any uncertainty that may arise

\footnotetext{
${ }^{7}$ Energy storage may mitigate this effect. However, storage options were considered with a capacity factor of zero in this analysis.

${ }^{8}$ A nuclear power plant uprate is defined as " $[\mathrm{t}]$ he process of increasing the maximum power level at which a commercial nuclear power plant may operate” (United States Nuclear Regulatory Commission 2016).
} 
in planned capacity additions (e.g., planned additions that may get delayed or cancelled). In addition, different technology types have varying lengths of time needed for planning and construction, which may distort the capacity additions that could be included in this analysis. Plants with longer planning periods are likely more inclined to report planned capacity additions than those with shorter planning or lead time periods. Policy mandates (such as state renewable portfolio standards and goals) are not considered for this analysis.

- Capacity estimates in this analysis do not include assumptions about nonscheduled relicensing, unplanned repowering, or other unplanned uprates and/or conversions. For example, according to this analysis, the current nuclear operating fleet in the United States decreases by $98 \%$ between 2015 and 2050; however, a nuclear facility may choose to invest in additional maintenance or upgrades of equipment, thereby extending the operation of the facility beyond its estimated lifespan. Repowering options are also not considered for renewable generation technologies. Relicensing, repowering, or other uprates and/or conversions will inevitably be a part of the options available for filling the opportunity space out to 2050 .

- Similarly, there are some generating units that are still in operation today even though they have exceeded their expected lifespan. In the ABB Velocity Suite data (2015), generators still in operation as of 2015 that do not have a scheduled retirement year but have exceeded the estimated lifespan of their generator fuel type have their expected retirement date set to January 1 of the following year. According to ABB Velocity Suite (2015), "[t]his does not mean that all of these units will retire that soon, only that they have been identified as likely to retire in the near future."

- Distributed generation was not included in this analysis. According to EIA, generation from distributed photovoltaics was $0.2 \%$ of total generation in the United States in 2014 (EIA 2015a). The analysis is based on utility-scale generation at the expected busbar load. However, this assumption does not limit distributed generation from being one of the generation options that could leverage the estimated opportunity space.

- Conversely, other assumptions made in this analysis may result in overestimating the generation from 2015 that may be available in the future, thereby effectively underestimating the overall opportunity space. These assumptions include excluding unscheduled early retirements, ignoring changes in capacity factors, excluding storage, and ignoring partial-year generation from retiring units. Again, there are several reasons for making these assumptions:

- This analysis does not include unscheduled economic or other early retirements. Projections for retirements generated from capacity expansion models (e.g., ReEDS, National Energy Modeling System) depend on a number of assumptions (e.g., policies and/or economic conditions) that can change significantly over time. For example, policies that regulate greenhouse gas emissions may cause some fossil fuel plants to retire early if they cannot meet the 
compliance requirements. This analysis is independent of the impact of policies or economic conditions that may force units to retire before their expected lifespan.

- This analysis assumes that capacity factors are constant throughout the timeframe of the report and uses 2014 capacity factors as the baseline. Capacity factors vary year by year and are based on several factors, such as dispatch economics, not just the performance of the unit. For example, changes in fuel prices can have a significant impact on dispatch and, in turn, a plant's capacity factor. The availability of renewable resources, such as levels of rainfall, changes annually and impacts a hydro-electric plant's capacity factor. In addition, as units age and technologies develop, new, more efficient units tend to come online, thereby out-competing older units and making them less economical to operate. As a result, this would likely decrease the dispatch and therefore the capacity factor of older units.

- This analysis assumes the capacity factor of energy storage units to be zero. Energy storage provides valuable services to the grid, such as shifting load or enhancing power quality and reliability. However, in doing so, it consumes more electricity than it provides to the grid. National capacity factors for energy storage were not available from EIA.

$\bigcirc$ Generating units typically retire part way through the year and may produce electricity for some fraction of their retirement year. This analysis assumes that the unit retires at the beginning of the retirement year, regardless of whether it is a scheduled or age-based retirement.

Lastly, because of data limitations, this analysis is focused on the contiguous United States and excludes Hawaii and Alaska. 


\section{Results}

This section describes the results from the opportunity space analysis. It includes a discussion of the national opportunity space (Section 3.1) and the opportunity space in the coastal regions (Section 3.2). State results are discussed and included in the appendix.

\subsection{National Opportunity Space}

The U.S. electricity generation in 2014 was approximately 4,100 TWh and composed of 38.5\% coal, $27.3 \%$ natural gas, $0.7 \%$ petroleum, $19.4 \%$ nuclear, $13.5 \%$ renewable resources, and $0.6 \%$ other generation technologies (Beiter 2015). Technologies that supply generation may not always be available, and as they age and retire the electrical system will require new sources of electricity to fill the gap between a growing demand and diminishing supply.

Figure 2 shows the electricity generation from different sources and the growth in the aggregated opportunity space over time for the contiguous United States. The electricity generation from operating generators at the beginning of 2015 was approximately $4 \%$ lower than the estimate reported in EIA (2015b) and Beiter (2015). This divergence can be attributed to differences in the inclusion of generation from units that came online during 2015, available capacity factor estimates, the consideration of distributed generation and nongrid-connected generation, and effects related to the import and export of electricity. The growth in opportunity space is a result of two primary factors: retirements and demand. Generating units are assumed to retire either based on scheduled retirement dates or a unit's age, whereas demand is assumed to grow steadily over time, as projected by EIA (2014).

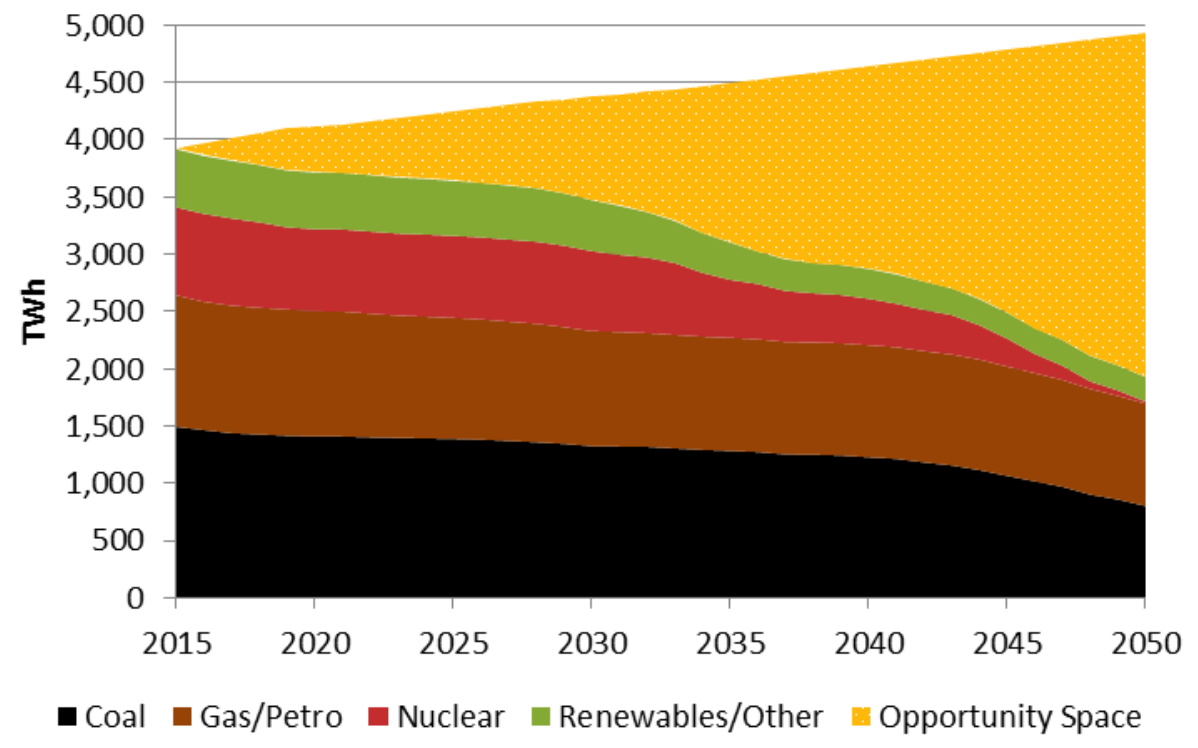

Figure 2. Opportunity space and projected net electricity generation from existing units for the entire United States (including coastal regions), from 2015 to 2050

Note: Imports to a region are considered part of the opportunity space and no assumption is made with regards to the share of exports and imports throughout the time period considered. 
According to the analysis provided in this report, the United States will approximately require an additional 3,000 TWh of electricity generation (corresponding to $77 \%$ of electricity demand in 2015 ) by 2050. Between 2015 and 2050, U.S. electricity demand is projected to grow by approximately $1,000 \mathrm{TWh}$, or $26 \%$. Because of scheduled and age-based power plant retirements, electricity generation from coal units that were operational in 2015 was estimated to decrease by $692 \mathrm{TWh}$, or 46\%; natural gas and petroleum by $256 \mathrm{TWh}$, or $22 \%$; nuclear by 749 TWh, or 98\%; and renewable and other fuel types by $292 \mathrm{TWh}$, or $58 \%$. These values are summarized in Table 3.

Table 3. U.S. Electricity Demand, Remaining Generation by Source, and Opportunity Space from 2015 to $2050^{9}$

\begin{tabular}{|l|r|r|r|r|r|}
\hline & \multicolumn{5}{|c|}{ TWh } \\
\hline Category & $\mathbf{2 0 1 5}$ & $\mathbf{2 0 2 0}$ & $\mathbf{2 0 3 0}$ & $\mathbf{2 0 4 0}$ & $\mathbf{2 0 5 0}$ \\
\hline Demand & 3,915 & 4,108 & 4,371 & 4,638 & 4,926 \\
\hline Coal & 1,493 & 1,409 & 1,325 & 1,227 & 801 \\
\hline Natural Gas/Petroleum & 1,148 & 1,092 & 1,003 & 978 & 892 \\
\hline Nuclear & 767 & 716 & 698 & 405 & 18 \\
\hline Renewables/Other & 507 & 495 & 445 & 259 & 214 \\
\hline Opportunity Space & 0 & 396 & 900 & 1,769 & 2,999 \\
\hline
\end{tabular}

\subsection{Regional Offshore Wind Opportunity Space}

One of the main objectives of this report is to determine the opportunity space for offshore wind. This involves focusing on five coastal regions: the Pacific Coast, Gulf Coast, Great Lakes, and North and South Atlantic, as defined in Figure 3. Each of the coastal regions has generation characteristics and demand projections that make their regional opportunity space unique.

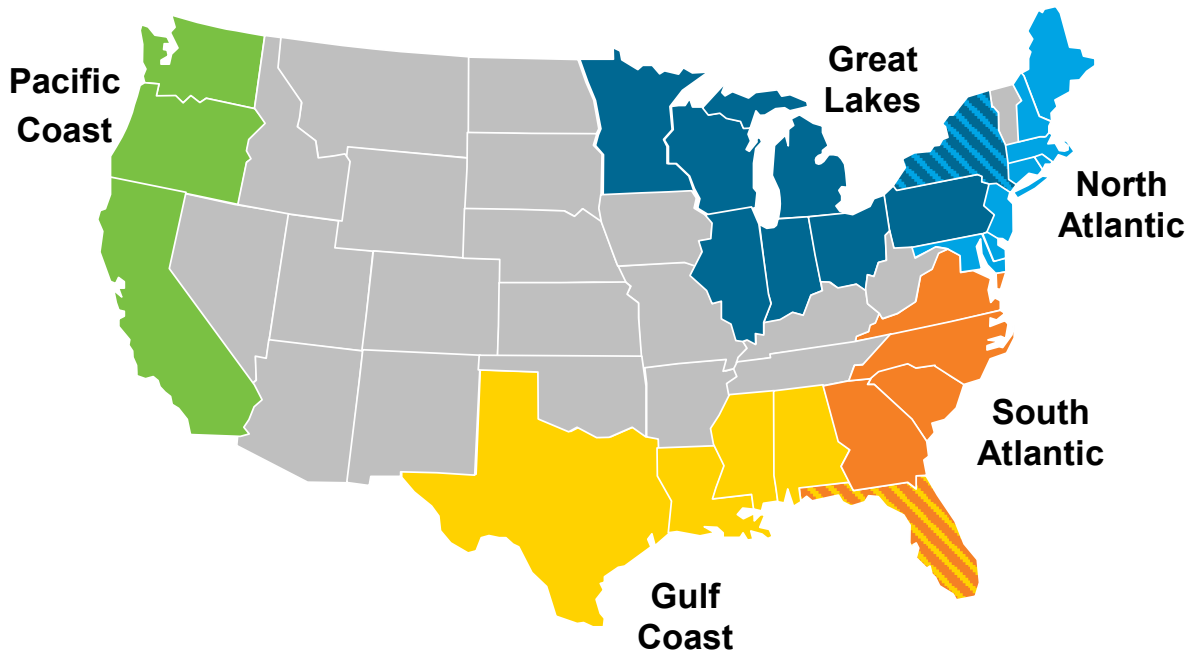

Figure 3. U.S. offshore wind regional map. Figure from the Wind Vision (DOE 2015)

Note: See footnotes 10 and 11 for a description of the regional assignment of Florida and New York

\footnotetext{
${ }^{9}$ The 2015 values for generation shown here are specific to this analysis and do not include generation from units that came online in 2015 nor units that retired in 2015.
} 
Figure 4 and Table 4 summarize the opportunity space analysis for each of the five coastal regions. Details on each region include the following:

- North Atlantic. The North Atlantic is the smallest of the five regions in terms of demand and largest in terms of number of states (eight states and a 50\% share of New York's demand and retirements). ${ }^{7}$ Compared to the other coastal regions, the North Atlantic sees little change in its expected demand, increasing from 378 TWh in 2015 to 389 TWh by 2050. Instead, the majority of the estimated opportunity space comes from estimated retirements. Like the Pacific Coast, the North Atlantic has very little existing coal generation within the region (4\% in 2015). The North Atlantic also has to import a significant portion $(28 \%)$ of generation to meet demand within the region in 2015. Retirements up to 2050 are associated with nuclear (-100\%), coal (-69\%), renewables/other (-49\%), and natural gas/petroleum (-40\%).

- South Atlantic. The South Atlantic comprises four states and a 50\% share of Florida's demand and retirements. ${ }^{8}$ It has a demand of 600 TWh in 2015, which increases to 803 TWh in 2050. In 2015, the majority of the generation is fairly evenly split between coal, natural gas/petroleum, and nuclear. By 2050, the region sees declines in generation from primarily nuclear $(-100 \%)$ and coal $(-50 \%)$. Renewables/other $(-48 \%)$ and natural gas/petroleum $(-19 \%)$ also decline, but at a lesser amount. This region's opportunity space is 555 TWh by 2050 .

- Great Lakes. The Great Lakes is the largest of the five coastal regions in terms of electricity demand, consisting of seven states and a 50\% share of New York's demand and retirements. ${ }^{10}$ The Great Lakes region has the largest share of coal generation (47\% in 2015). It also has the largest share of retiring generation (63\%) between 2015 and 2050. Retirements between 2015 and 2050 are largely regarding nuclear $(-100 \%)$ and coal $(-59 \%)$. In the same time period, natural gas/petroleum and renewables/other decrease by $25 \%$ and $69 \%$, respectively, but represent a smaller portion of the overall generation in 2015. The opportunity space for this region is $688 \mathrm{TWh}$ by 2050 - the highest among all the regions - largely because many existing coal and nuclear power plants will be nearing retirement age and the relative size of the region compared to the other coastal regions in terms of overall electricity demand.

- Gulf Coast. The Gulf Coast is the second largest region in terms of electricity demand, consisting of four states and a 50\% share of Florida's demand and retirements. ${ }^{11}$ Of the coastal regions, this region has the greatest share of natural gas/petroleum starting in 2015 (24\%), and an estimated opportunity space by 2050 of 502 TWh. The largest relative decrease in retirements can be ascribed to nuclear $(-92 \%)$, followed by renewables/other $(-86 \%)$, natural gas/petroleum $(-20 \%)$, and coal $(-16 \%)$. Compared to the other coastal regions, the Gulf Coast has the lowest share of retired generation $(35 \%)$ up to 2050. It is the region with the highest overall growth in demand, with an estimated $231 \mathrm{TWh}$ of additional demand required between 2015 and 2050 and a Compound Annual Growth Rate (CAGR) of $0.91 \%$.

\footnotetext{
${ }^{10}$ New York's demand and retirements are allocated to the Great Lakes (50\%) and North Atlantic (50\%) regions.

${ }^{11}$ Florida's demand and retirements are allocated to the Gulf of Mexico (50\%) and South Atlantic (50\%).
} 
- Pacific Coast. The Pacific Coast comprises only three states, and a demand of $421 \mathrm{TWh}$ in 2015. This region has the greatest share of renewable generation (52\% in 2015) compared to the other coastal regions in this analysis. This region also has the smallest share of coal generation (3\% of in 2015) and nuclear generation (7\% in 2015). Coal generation declines to zero early in the projection period based on the retirement assumptions used in this analysis, whereas nuclear generation does not retire completely until 2046. A considerable share of the opportunity space for the Pacific Coast region comes from growth in demand, which has a CAGR of $0.86 \%$, only superseded by the corresponding rate in the Gulf Coast region of $0.91 \%$. In 2015 , the region already had an opportunity space of $65 \mathrm{TWh}$. This difference between demand and generation is currently being met with imports from neighboring regions and Canada. 


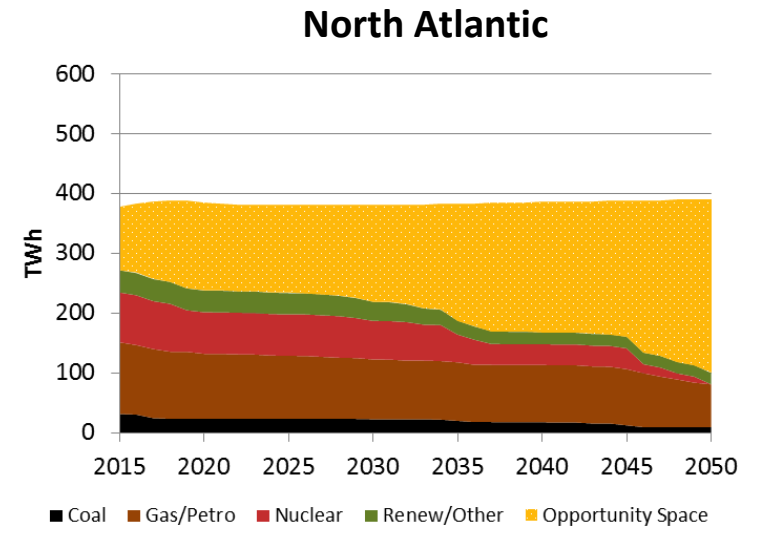

\section{Great Lakes}

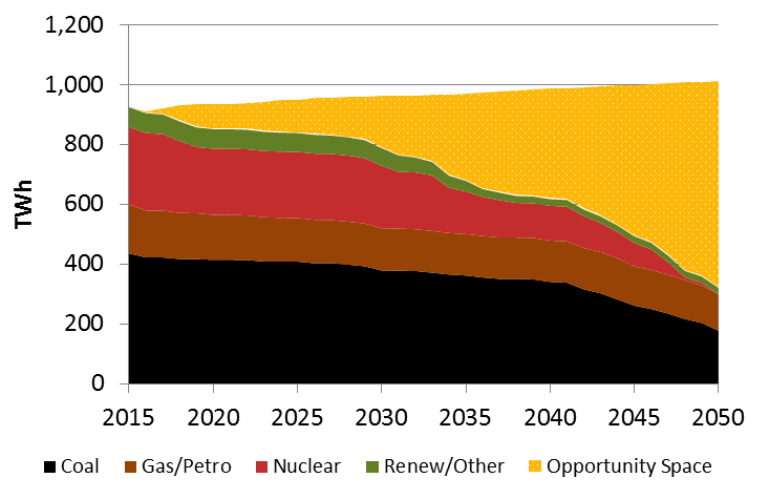

Pacific Coast

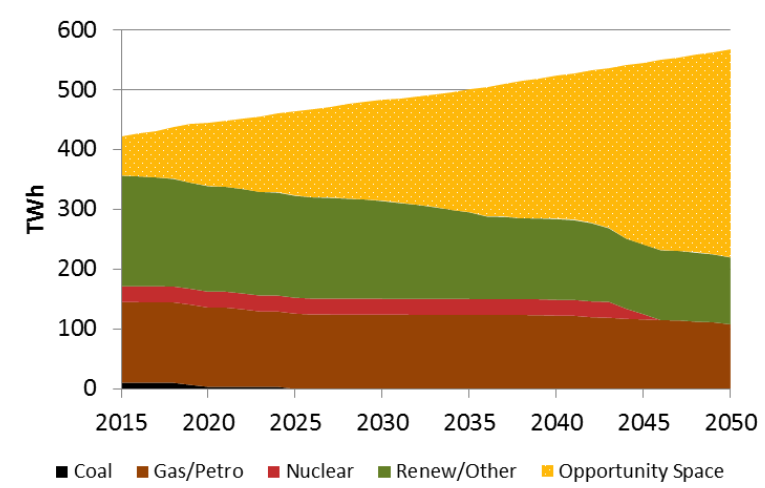

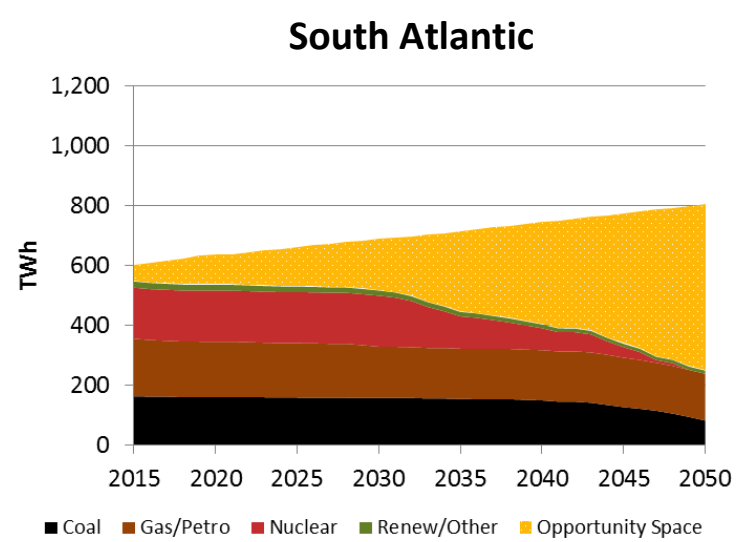

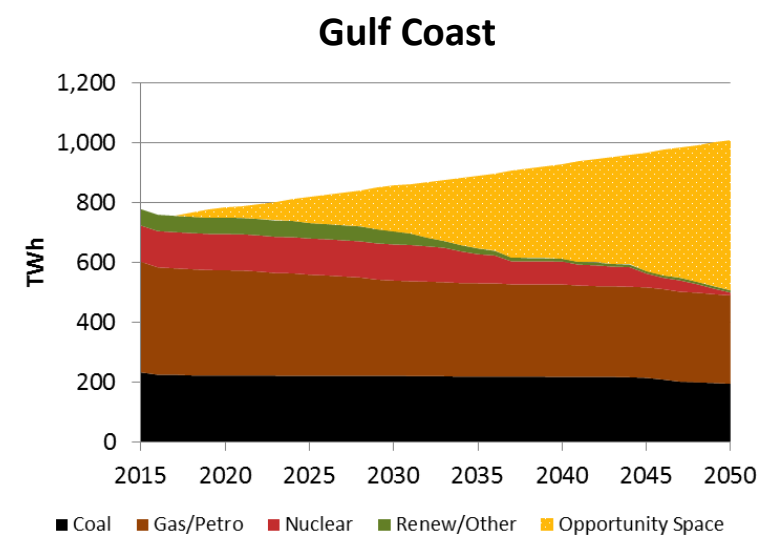

All Coastal Regions

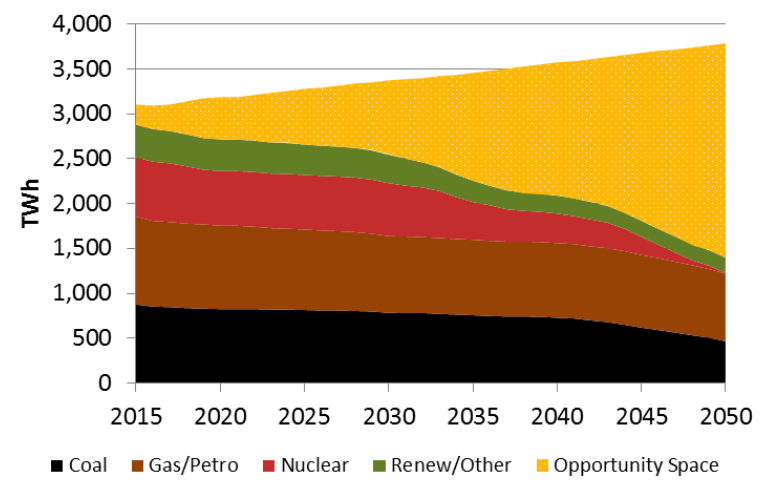

Figure 4. The opportunity space and projected electricity generation from existing units in each coastal region (including all coastal regions) from 2015 to 2050

Note: Imports to a region are considered part of the opportunity space and no assumption was made with regards to the share of exports and imports throughout the time period considered.

The results from this analysis can be compared to estimates of the resource potential of any generation technology. For offshore wind, the 2016 Offshore Wind Energy Resource Assessment for the United States report (Musial et al. 2016) recently estimated the total technical potential of offshore wind in the nation to be more than 7,200 TWh/yr. In this report, offshore wind technical resource potential is defined as the subset of gross recoverable resource potential that can be considered recoverable under available 
technological and turbine performance conditions while considering land-use and environmental siting constraints (Musial et al. 2016).

This analysis indicates a total U.S. opportunity space of nearly 3,000 TWh to be available by 2050. This amount is based on an average national annual load growth of $0.66 \%$ (CAGR) and cumulative retirements of nearly 2,000 TWh between 2015 and 2050. For coastal regions alone, the analysis shows that nearly 2,400 TWh of opportunity space will be available by 2050 , comprising approximately $80 \%$ of the total U.S. opportunity space. The technical resource potential for offshore exceeds the opportunity space in coastal regions by a multiple of three.

Table 4. The Opportunity Space and Scheduled/Age-Based Retirements for the Coastal Regions from 2015 to 2050

\begin{tabular}{|c|c|c|c|c|c|c|}
\hline & & & & & & \\
\hline Region & Category & 2015 & 2020 & 2030 & 2040 & 2050 \\
\hline & Demand & 378 & 384 & 381 & 385 & 389 \\
\hline & Coal & 32 & 24 & 23 & 18 & 10 \\
\hline North & Nat. Gas/Petroleum & 120 & 109 & 100 & 96 & 72 \\
\hline Atlantic & Nuclear & 83 & 69 & 64 & 35 & 0 \\
\hline & Renewables/Other & 37 & 36 & 32 & 20 & 19 \\
\hline & Opportunity Space & 180 & 145 & 161 & 216 & 289 \\
\hline & Demand & 600 & 633 & 687 & 743 & 803 \\
\hline & Coal & 163 & 160 & 158 & 149 & 82 \\
\hline South & Nat. Gas/Petroleum & 193 & 186 & 171 & 168 & 156 \\
\hline Atlantic & Nuclear & 170 & 170 & 170 & 73 & 0 \\
\hline & Renewables/Other & 21 & 20 & 17 & 13 & 11 \\
\hline & Opportunity Space & 53 & 98 & 170 & 339 & 555 \\
\hline & Demand & 926 & 932 & 959 & 984 & 1,009 \\
\hline & Coal & 437 & 415 & 380 & 342 & 178 \\
\hline Great & Nat. Gas/Petroleum & 163 & 150 & 141 & 138 & 122 \\
\hline Lakes & Nuclear & 259 & 221 & 209 & 116 & 0 \\
\hline & Renewables/Other & 66 & 65 & 59 & 22 & 21 \\
\hline & Opportunity Space & 0 & 80 & 170 & 365 & 688 \\
\hline & Demand & 778 & 783 & 856 & 930 & 1,009 \\
\hline & Coal & 233 & 222 & 222 & 218 & 195 \\
\hline Gulf & Nat. Gas/Petroleum & 370 & 352 & 318 & 308 & 295 \\
\hline Coast & Nuclear & 121 & 121 & 121 & 77 & 9 \\
\hline & Renewables/Other & 55 & 55 & 45 & 10 & 8 \\
\hline & Opportunity Space & 0 & 33 & 151 & 316 & 502 \\
\hline & Demand & 421 & 444 & 482 & 523 & 567 \\
\hline & Coal & 11 & 4 & 0 & 0 & 0 \\
\hline Pacitic & Nat. Gas/Petroleum & 135 & 133 & 124 & 123 & 108 \\
\hline & Nuclear & 27 & 27 & 27 & 27 & 0 \\
\hline & Renewables/Other & 185 & 176 & 163 & 135 & 112 \\
\hline
\end{tabular}




\begin{tabular}{|c|l|r|r|r|r|r|}
\hline \multicolumn{2}{|c|}{} & \multicolumn{5}{|c|}{ (TWh) } \\
\hline Region & Category & $\mathbf{2 0 1 5}$ & $\mathbf{2 0 2 0}$ & $\mathbf{2 0 3 0}$ & $\mathbf{2 0 4 0}$ & $\mathbf{2 0 5 0}$ \\
\hline & Opportunity Space & 65 & 106 & 168 & 239 & 348 \\
\hline \multirow{4}{*}{$\begin{array}{c}\text { All } \\
\text { Coastal } \\
\text { Regions }\end{array}$} & Demand & 3,103 & 3,177 & 3,365 & 3,564 & 3,779 \\
\cline { 2 - 7 } & Coal & 875 & 825 & 782 & 728 & 465 \\
\cline { 2 - 7 } & Nat. Gas/Petroleum & 981 & 930 & 855 & 833 & 754 \\
\cline { 2 - 7 } & Nuclear & 660 & 609 & 591 & 328 & 9 \\
\cline { 2 - 7 } & Renewables/Other & 364 & 352 & 316 & 200 & 170 \\
\cline { 2 - 7 } & Opportunity Space & 298 & 462 & 821 & 1,476 & 2,380 \\
\hline
\end{tabular}

Note: Imports to a region are considered part of the opportunity space and no assumption was made with regards to the share of exports and imports throughout the time period considered. 


\section{Conclusions}

The purpose of this analysis was to provide a high-level estimate of the additional electricity generation that will be required to meet demand in future years. The opportunity space was reported for the contiguous United States and 28 coastal states (divided into five offshore wind regions). The latter grouping helps provide an assessment of how much opportunity space is available relative to noncoastal states and identifies the upper bound and geographic distribution of demand that can be met by offshore wind generation.

The analysis results revealed that the 28 coastal states will have a total of 2,400 TWh of opportunity space available for new generation capacity by 2050. Opportunity space in U.S. coastal regions accounts for approximately $80 \%$ of the total U.S. opportunity space $(3,000 \mathrm{TWh})$ by 2050 . The coastal opportunity space in 2050 is distributed among the Great Lakes (688 TWh), South Atlantic (555 TWh), Gulf Coast (502 TWh), Pacific (348 TWh), and North Atlantic (289 TWh) regions. The majority of retirements in absolute terms across these regions come from nuclear (-651 TWh, or $44 \%$ of total retirements), followed by coal $(-410 \mathrm{TWh}$, or $28 \%$ of total retirements), natural gas/petroleum (-227 TWh, or $15 \%$ of total retirements), and renewables/other (-194 TWh, or $13 \%$ of total retirements). The analysis also found that the technical resource potential from offshore wind (Musial et al. 2016) exceeded the total expected opportunity space for all of the coastal regions by a factor of three.

Some limitations apply to this analysis. These include the assumption of static import-export relationships and the nonconsideration of integration challenges, planned or scheduled capacity additions, unscheduled economic or other early retirements (e.g., as a result of policies that may force units to retire before their expected lifespan), policy mandates, nonscheduled relicensing, unplanned repowering, or other unplanned uprates and/or conversions. In addition, capacity factors are held constant throughout the timeframe of this report. Significant reductions from energy efficiency measures are not explicitly considered to adjust demand (load) projections.

Future areas of study using this approach may reflect an improved understanding of any of the various factors affecting the opportunity space such as:

- Quantifying the impacts of increasing fuel prices or regulations that may cause premature retirement of the existing fleet

- Including assumptions about repowering, uprates, or distributed generation that would lead to the prolonged life of the existing fleet

- Conducting a range of sensitivities related to fuel prices, load, and other factors.

Despite the scope limitations within this report, our findings suggest that the offshore wind potential considerably exceeds the future opportunity space available in the United States and may be one of the electricity generation options used to meet electricity demand in the future. 


\section{References}

ABB Velocity Suite. 2015. Velocity Suite Database. Atlanta, GA: Ventyx/ABB. Accessed September 2015.

Beiter. 2015. “2014 Renewable Energy Data Book” DOE/GO-102015-4724. U.S. Department of Energy (DOE), Energy Efficiency \& Renewable Energy (EERE), Washington, DC (US).

Beiter, P. and W. Musial. 2016. Terminology Guideline for Classifying Offshore Wind Energy Resources (Technical Report), NREL/TP-5000-65451, National Renewable Energy Laboratory (NREL), Golden, CO (US).

Beiter, P., W. Musial, E. Lantz, L. Kilcher, R. Damiani, M. Maness, S. Sirnivas, T. Stehly, V. Gevorgian, M. Mooney, G. Scott. 2016. A Spatial-Economic Cost Reduction Pathway Analysis for U.S. Offshore Wind Energy Development from 2015-2030 (Technical Report), NREL/TP5000 66522, National Renewable Energy Laboratory (NREL), Golden, CO (US).

Catapult. 2015. Cost Reduction Monitoring Framework. Innovate UK Technology Strategy Board. Accessed May 2016: https://ore.catapult.org.uk/documents/10619/110659/ORE+Catapult+report+to+the+OWPB/a8c7 3f4e-ba84-493c-8562-acc87b0c2d76.

Danish Ministry of Foreign Affairs. 2015. “A World Leader in Wind Energy.” Accessed February 2016. http://denmark.dk/en/green-living/wind-energy/.

EIA (Energy Information Administration). 2014. Annual Energy Outlook 2014. DOE/EIA-0383 (2015). Washington, DC. Accessed January 2016:

http://www.eia.gov/forecasts/aeo/er/pdf/0383er(2016).pdf.

EIA. 2015a. "Electric Power Monthly, Table 1.1.A. Net Generation from Renewable Sources: Total (All Sectors).” Accessed January 2016: http://www.eia.gov/electricity/monthly/.

EIA. 2015b. "Form EIA-860 detailed data." Accessed February 2016: https://www.eia.gov/electricity/data/eia860/.

EIA. 2015c. "Electric Power Monthly, Table 6.7.A. Capacity Factors for Utility Scale Generators Primarily Using Fossil Fuels," http://www.eia.gov/electricity/monthly/.

EIA. 2015d. "Electric Power Monthly, Table 6.7.B. Capacity Factors for Utility Scale Generators Not Primarily Using Fossil Fuels." Accessed September 2015:

http://www.eia.gov/electricity/monthly/.

EIA 2015e. "Electricity Data Browser, Net generation for all sectors, monthly." Accessed January 2016: http://www.eia.gov/electricity/data/browser/.

EIA. 2015f. "Short-Term Energy Outlook.” Accessed March 2016:

http://www.eia.gov/forecasts/steo/report/electricity.cfm. 
EIA. 2015g. "Form EIA-923 detailed data." Accessed March 2016:

https://www.eia.gov/electricity/data/eia923/.

Sullivan, P., W. Cole, N. Blair, E. Lantz, V. Krishnan, T. Mai, D. Mulcahy, G. Porro. 2015. 2015 Standard Scenarios Annual Report: U.S. Electric Sector Scenario Exploration (Technical Report). NREL/TP-6A20-64072. National Renewable Energy Laboratory (NREL), Golden, CO (US). http://www.nrel.gov/docs/fy15osti/64072.pdf.

The Carbon Trust. 2015. "Floating Offshore Wind: Market and Technology Review." Prepared for the Scottish Government. Accessed May 2016.

https://www.carbontrust.com/media/670664/floating-offshore-wind-market-technologyreview.pdf.

Moné, C., T. Stehly, B. Maples, E. Settle. 2015. 2014 Cost of Wind Energy Review (Technical Report). NREL/TP-6A20-64281. National Renewable Energy Laboratory (NREL), Golden, CO (US). http://www.nrel.gov/docs/fy16osti/64281.pdf.

Musial, W., D. Heimiller, P. Beiter, G. Scott. 2016. Offshore Wind Energy Resource Assessment for the United States (Technical Report). NREL/TP-5000-66599. National Renewable Energy Laboratory (NREL), Golden, CO (US).

RenewableUK. 2016. "Offshore Wind.” Accessed February 2016. http://www.renewableuk.com/en/renewable-energy/wind-energy/offshore-wind/.

Short, W., P. Sullivan, T. Mai, M. Mowers, C. Uriarte, N. Blair, D. Heimiller, A. Martinez. 2011. Regional Energy Deployment System (ReEDS) (Technical Report). NREL/TP-6A20-46534. National Renewable Energy Laboratory (NREL), Golden, CO (US). http://www.nrel.gov/docs/fy12osti/46534.pdf.

Smith, A., T. Stehly, W. Musial. 2015. 2014-2015 Offshore Wind Technologies Market Report (Technical Report). NREL/TP-5000-64283. National Renewable Energy Laboratory (NREL), Golden, CO (US). http://www.nrel.gov/docs/fy15osti/64283.pdf.

U.S. Department of Energy. 2015. Wind Vision: A New Era for Wind Power in the United States. DOE/GO-102015-4557. U.S. Department of Energy Office of Energy Efficiency \& Renewable Energy, Washington, D.C. (US). http://www.energy.gov/sites/prod/files/WindVision_Report_final.pdf.

United States Nuclear Regulatory Commission. 2016. "Power Uprates." Last modified April 14, 2016. http://www.nrc.gov/reactors/operating/licensing/power-uprates.html. 


\section{Appendix}

\section{State-Level Opportunity Space}

The state-level opportunity space for renewable technologies is more nuanced than what is presented at the national or regional level. The primary challenge in comparing state-level data is interstate trading for electricity. Figure A-1, which includes the opportunity space for renewable technologies for California (left) and Arizona (right), illustrates this point. There is a significant difference in 2015 between available electricity generation and demand for California, whereas there is excess generation in Arizona. This difference is because of the fact that the state-level data looks at generation that occurs within state boundaries and not necessarily in relation to the end user, which is harder to allocate and subject to change year to year. California is a net importer of electricity, due in part to excess electricity generation from states such as Oregon, Washington, and Arizona. As a result, an opportunity space for these three states does not appear until 2018, 2025, and 2038, respectively.
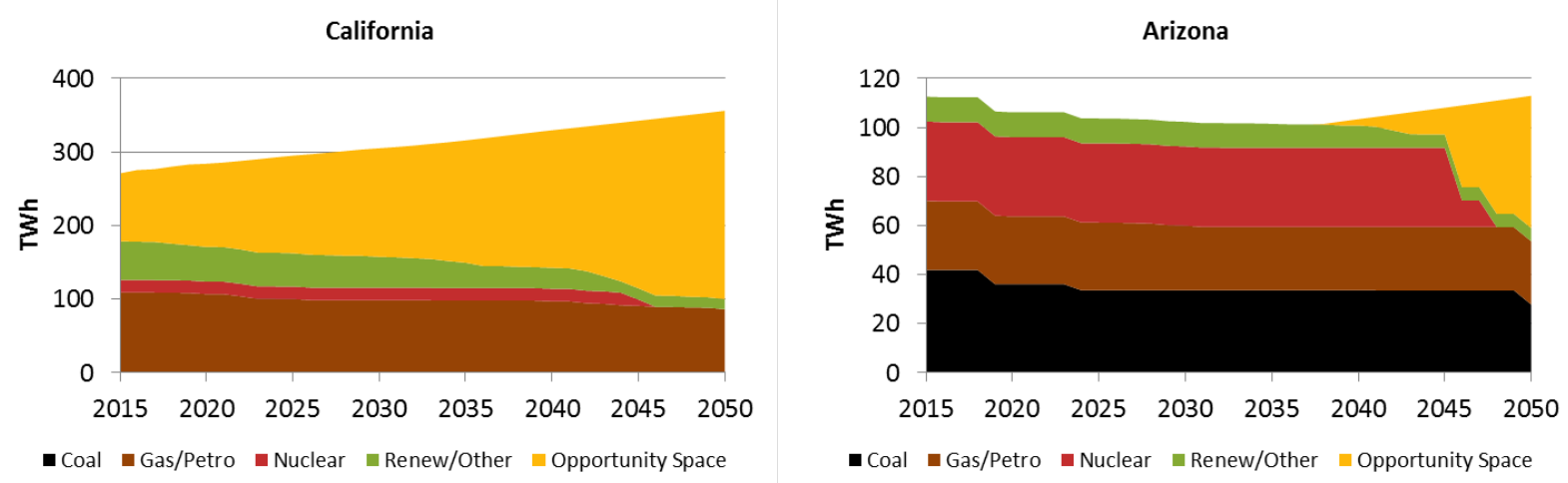

Figure A-1. The opportunity space and projected electricity generation from existing units for California (left) and Arizona (right) from 2015 to 2050 
Table A-1.State-Level Opportunity Space from 2015 to 2050

\begin{tabular}{|c|c|c|c|c|c|}
\hline \multirow{2}{*}{ State } & \multicolumn{5}{|c|}{ (TWh) } \\
\hline & 2015 & 2020 & 2030 & 2040 & 2050 \\
\hline Alabama & 0 & 0 & 0 & 33 & 59 \\
\hline Arkansas & 0 & 0 & 6 & 25 & 30 \\
\hline Arizona & 0 & 0 & 0 & 3 & 54 \\
\hline California & 92 & 113 & 148 & 187 & 256 \\
\hline Colorado & 1 & 5 & 13 & 28 & 43 \\
\hline Connecticut & 1 & 3 & 3 & 11 & 22 \\
\hline Delaware & 5 & 6 & 6 & 6 & 9 \\
\hline Florida & 16 & 40 & 76 & 127 & 174 \\
\hline Georgia & 27 & 36 & 50 & 79 & 130 \\
\hline lowa & 0 & 0 & 6 & 27 & 34 \\
\hline Idaho & 10 & 12 & 15 & 21 & 25 \\
\hline Illinois & 0 & 0 & 20 & 53 & 141 \\
\hline Indiana & 0 & 8 & 18 & 33 & 56 \\
\hline Kansas & 0 & 0 & 3 & 17 & 36 \\
\hline Kentucky & 10 & 22 & 34 & 40 & 65 \\
\hline Louisiana & 3 & 12 & 31 & 45 & 74 \\
\hline Massachusetts & 26 & 40 & 41 & 46 & 49 \\
\hline Maryland & 42 & 44 & 48 & 65 & 74 \\
\hline Maine & 2 & 4 & 4 & 8 & 8 \\
\hline Michigan & 16 & 30 & 40 & 77 & 103 \\
\hline Minnesota & 18 & 22 & 40 & 68 & 74 \\
\hline Missouri & 0 & 3 & 15 & 29 & 72 \\
\hline Mississippi & 4 & 7 & 12 & 17 & 32 \\
\hline Montana & 0 & 0 & 0 & 0 & 0 \\
\hline North Carolina & 8 & 17 & 32 & 65 & 139 \\
\hline North Dakota & 0 & 0 & 0 & 0 & 0 \\
\hline Nebraska & 0 & 0 & 0 & 14 & 18 \\
\hline New Hampshire & 0 & 0 & 0 & 0 & 7 \\
\hline New Jersey & 35 & 41 & 40 & 46 & 68 \\
\hline New Mexico & 0 & 0 & 5 & 8 & 20 \\
\hline Nevada & 0 & 3 & 10 & 17 & 28 \\
\hline New York & 0 & 23 & 42 & 68 & 93 \\
\hline Ohio & 32 & 39 & 52 & 68 & 135 \\
\hline Oklahoma & 0 & 0 & 12 & 27 & 32 \\
\hline Oregon & 0 & 5 & 12 & 25 & 35 \\
\hline Pennsylvania & 0 & 0 & 0 & 0 & 82 \\
\hline Rhode Island & 2 & 3 & 3 & 3 & 6 \\
\hline South Carolina & 0 & 0 & 0 & 34 & 77 \\
\hline South Dakota & 1 & 2 & 3 & 6 & 9 \\
\hline Tennessee & 24 & 35 & 55 & 72 & 123 \\
\hline Texas & 0 & 19 & 83 & 157 & 250 \\
\hline Utah & 0 & 0 & 0 & 0 & 6 \\
\hline Virginia & 27 & 36 & 52 & 98 & 121 \\
\hline Vermont & 4 & 5 & 5 & 6 & 6 \\
\hline Washington & 0 & 0 & 9 & 27 & 57 \\
\hline Wisconsin & 24 & 29 & 34 & 42 & 50 \\
\hline West Virginia & 0 & 0 & 0 & 0 & 14 \\
\hline Wyoming & 0 & 0 & 0 & 4 & 9 \\
\hline
\end{tabular}

Note: Adding the opportunity space for a group of states or the entire United States in a given year does not equal the total opportunity space within a region or the United States, as states with a zero value for the opportunity space likely have excess generation that could be used to supply generation in an adjacent state. This analysis did not include Hawaii and Alaska. Offshore states are shaded in blue. 